\title{
Üstün Yeteneklilerin Eğitiminde Ayrı Okullar: Amerika'daki Üstün Yetenekliler Okullarının Karşılaştırmalı Olarak İncelenmesi
}

\author{
MAHMUT ÇITIL \\ SIDIKA ERSOY \\ MERVE ÖZDEMIR-KILIC \\ AYSIL AĞAYA
}

\section{Özet}

Üstün yeteneklilerin eğitimi alanında çoğunlukla kullanılan üç temel strateji bulunmaktadır. Bunlar gruplama, hızlandırma ve zenginleştirmedir. Gruplama uygulamaları üstün yetenekli öğrencilerin kendisi gibi akranlarıyla ayrı bir okulda ya da sınıfta öğrenim görmesi ya da normal gelişim gösteren akranlarıyla bir arada eğitim görmesi şeklinde yapılabilmektedir. Türkiye'de üstün yetenekliler normal gelişim gösteren akranlarıyla aynı ortamda öğrenim

- ARASTIRMA MAKALESI-

MAHMUT ciTiL, mahmutcitil@hotmail.com Gazi Üniversitesi, Gazi Eğitim Fakültesi, Özel Eğitim Bölümü, Üstün Zekâlılar Eğitimi A.B.D. ORCID: https://orcid.org/0000-0001-7607-6595

SIDIKA ERSOY, s.ersoy1988@gmail.com

Gazi Üniversitesi, Gazi Eğitim Fakültesi, Özel Eğitim Bölümü ORCID: https://orcid.org/0000-0002-7168-744X

MERVE ÖZDEMIR-KILIC, merveozdemir362@gmail.com Gazi Üniversitesi, Gazi Eğitim Fakültesi, Özel Eğitim Bölümü ORCID: https://orcid.org/0000-0002-1768-0095 
görmektedirler. Üstün yetenekli öğrencilere yönelik açılan ayrı okulların içeriği, avantaj ve dezavantajları ise pratikte yeterince bilinmemektedir. Bu araştırmanın amacı üstün yeteneklilere yönelik açllan ayrı okulları belli değişkenlere göre incelemektir. Tarama modelinde betimsel bir çalışma olan bu araştırmada veriler doküman analizi yöntemi ile analiz edilmiştir. Bu kapsamda ABD ve Kanada'da hizmet veren 10 üstün yetenekliler okulu özel/devlet, ücreti, kuruluş tarihi, sınıf düzeyleri, kabul ve tanılama şartları, okulda kullanılan program modelleri, müfredatları, sınıf mevcutları, sosyal, kültürel ve sportif faaliyetleri gibi değişkenlere göre analiz edilmiştir. Bu okullar tanınırlık ve internet sitelerinde sundukları içeriğin zenginliğine göre seçilmiştir. Elde edilen bulgulara göre, okulların büyük çoğunluğunun özel okullar olduğu, bu okulların yıllık 10.00055.000 dolar arasında ücretleri olduğu, kuruluş tarihlerinin 1870-2017 arasında değiştiği, hemen her eğitim düzeyinde (ilk, orta, lise) hizmet sunulduğu, hemen her okulun kendi tanılama modeli olduğu ve okullara kabulde zekâ testlerinin belirleyici olduğu, okullarda müfredat zenginleştirme ve hızlandırma uygulamalarının yapıldığı, ayrıca çok çeşitli sosyal, kültürel ve sportif faaliyetleri olduğu anlaşılmıştır. Genel olarak değerlendirildiğinde Amerika'da üstün yeteneklilere yönelik okulların çok köklü bir geçmişi olduğu günümüzde de yeni okulların açıldığı anlaşılmıştır. Okulların yapısı ve eğitim içeriği incelendiğinde üstün yetenekli öğrencilere çok iyi imkânlar sunulduğu görülmektedir. Türkiye'de de kamu ve özel sektörün bu tip okullar açması ve etkisine bakılmasının alana ve eğitim sistemine katkı getireceği kanaati tarafımızca oluşmuştur.

Anahtar kelimeler: Üstün yetenek, gruplama, ayrı okul

\section{Abstract}

There are three basic strategies used in the field of gifted education. These are grouping, acceleration and enrichment. Grouping practices are conducted as programs in which all gifted students are educated with their peers in a separate school or classroom, or educated with their typical achieving peers in their regular classroom. The gifted students in Turkey are educated with their typical achieving peers in their regular classroom. The content, advantages and disadvantages of the separate schools founded for gifted students are not sufficiently known in practice. The aim of this research is to examine the separate schools founded for gifted students according to certain variables. In this research, designed as a descriptive study in the survey model, the data were analyzed by content analysis. In this context, 10 gifted schools providing service in the USA and Canada analyzed according to variables: private/state, fee, date of establishment, class levels, admission and identification conditions, program models used in school, curriculum, class sizes, social, cultural and sports activities. These schools have been selected for recognition and the richness 
of the content they offer on their websites. The findings show that, the vast majority of schools are private schools, these schools have annual fees between 10000-55000 dollars, the dates of their establishment vary between 18702017, these schools offer services at almost every educational level (primary, secondary, high school), almost every school has its own identification model and intelligence tests are determinant in admission to schools, curriculum enrichment and acceleration practices are carried out in schools, and there are a wide variety of distinctive social, cultural and sports activities. When evaluated in general, it is understood that schools for gifted students in America have a long-established history and new schools are founded today. When the structure and educational content of the schools are investigated, it is seen that remarkable opportunities are provided to gifted students. Consequently, we believed that the foundation of such schools by the public and private sector and the investigation of the effects of these schools on gifted education will contribute to the education system in Turkey.

Keywords: Gifted, grouping, separate school

\section{Giriş}

Üstün yetenekli bireylerin çözdükleri problemler, ortaya koydukları fikir ve ürünler sadece kendi toplumlarına değil tüm insanlığa faydalı olmuştur. Hemen her toplumda bulunan üstün yetenekli bireyler eğer uygun imkân ve ortamlar sağlanırsa bu katkıyı sürdürebilmektedirler. Bu kişilerin yaratıcı düşünce ve fikirlerine değer veren toplumlar bundan azami ölçüde yararlanabilmişlerdir. Türkiye'de özel eğitim alanının kurucusu olan rahmetli Mitat Enç "dünya tarihinden yaklaşık beş yüz seçkin kişiyi çıkarsak, taş devrine dönerdik" demiştir (Enç, 2005). İnsanlık ve toplum adına bu kadar önemli olan kişileri eğitmek de bir o kadar önemlidir. Üstün yetenekliler alanında Enderun dışında sistemli eğitim-öğretim uygulamalarının 20. yüzyıldan itibaren başladığı görülmektedir. Hem ikinci dünya savaşı döneminde hem de soğuk savaş döneminin bilgi ve istihbarat mücadelesi içerisinde bilim insanları ve üstün yetenekli kişiler tüm güçlü devletlerin ilgisini çekmeye başlamıştır (Çitil, 2016). Rusların Sputnik uzay aracını uzaya fırlattığı tarih olan 1957'de başta ABD olmak üzere birçok ülkenin konuya ilgisi artmıştır. Bu dönemde birçok ülke bünyelerindeki üstün beyinleri kendi kontrollerinde tutmak ve bu kişileri en iyi şekilde yetiştirmek için önlemler alma yoluna gitmiştir. Gelişmiş batı toplumları dışında Japonya, Kore ve Çin gibi Uzak Doğu ülkelerinin teknolojik ve ekonomik atılımlarında kurdukları eğitim sistemlerinin etkisi inkâr edilemez (Çitil, 2016). Bu bağlamda ülke 
yöneticileri üstün yetenekli öğrenciler için özel okul, sınıf ya da modellere ilişkin yasal düzenlemelere ve uygulamalara başlamış, araştırmacılar ise bu çocukların tanılanması için araçlar, eğitimleri için stratejiler ve yöntemler geliştirmiştir.

Üstün yetenekli çocuklar için geliştirilmiş olan eğitim önlemleri çeşitli model ve stratejilerden oluşmaktadır. Günümüzde üstün yeteneklilerin eğitimi alanında kullanılan üç temel strateji bulunmaktadır (Callard-Szulgit, 2010; Sak, 2010). Bunlar gruplama, hızlandırma ve zenginleştirmedir. Hızlandırma, akranlarına göre hızlı öğrenme ve gelişim özelliği gösteren öğrencilerin öğrenme ve gelişim hızlarına uygun öğretim programlarına devam etmeleridir (Sak, 2010). Okula erken başlatma, sınıf atlatma ve üst sınıftan ders alma, üniversiteye erken başlatma, IB, ikili kayıt, onur kayıtları, ileri yerleştirme sınıfları, ders hızlandırması, sınavla ders geçme gibi farklı hızlandırma uygulamaları da bulunmaktadır (Sak, 2010; Tortop, 2012). Zenginleştirme uygulaması ise üstün yetenekli çocukların kendi akranlarıyla birlikte normal sınıflarda eğitim görmelerine rağmen programların gereksinmelerine yanıt verecek şekilde çeşitlendirilmesi ve zenginleştirilmesi yoluyla yapılan uygulamalardır (Akkanat, 2004). Ataman'a (2009) göre zenginleştirme "müfredata derinlemesine ve genişliğine eklemeler yapma, bireyin gereksinimine göre müfredatı ilerletme, aşamaların belirleme, ilgi ve gereksinimlere göre materyalleri çeşitlendirme, yaratıcılık ve eleştirisel düşünmeyi, problem çözme, iletişim ve toplumsal becerileri geliştirme"yi içeren uygulamalardır. Gruplama uygulamaları ise üstün yetenekli öğrencilerin kendisi gibi akranlarıyla ayrı bir okulda ya da sınıfta öğrenim görmesi ya da normal gelişim gösteren akranlarıyla bir arada eğitim görmesi şeklinde yapılabilmektedir (Delcourt vd., 2007; Van der Meulen vd., 2014).

Gruplama uygulamaları süresi bakımından tam zamanlı ya da yarı zamanlı, içeriği bakımından homojen ya da heterojen olarak farklılaşmaktadır. Tam zamanlı gruplama uygulamaları "Homojen Gruplar: sinıflar arası özel

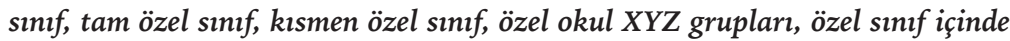
benzer gruplar; Heterojen Gruplar: okul içinde okul, karma sinıf ve normal sinıfta öğretim" gibi çeșitli uygulamalardan oluşmaktadır (Sak, 2010, s.117). Yarı zamanlı gruplama uygulamaları ise "Homojen: Kaynak oda, derse dayalı tekrarlı gruplar, sınıf içi benzer yetenek grupları; Heterojen: sınıf içi karışık yetenek grupları ve sınıf içi çok düzeyli gruplar" şeklinde ayrılmaktadır (Sak, 2010, s.117). Burada bahsi geçen gruplama türleri başta ABD olmak üzere birçok ülkede uygulanmaktadır. Türkiye'de ise gruplama uygulamaları çok sınırlıdır. Ülkemizde yarı zamanlı homojen uygulamalar olduğu söylenebilir. Bu kapsamda okullarda bulunan destek eğitim odaları ve okul dışında özel yetenekli öğrencilere hizmet veren Bilim ve Sanat Merkezleri en yaygın 
gruplama ve eğitim ortamlarına örnek olarak verilebilir. Ülkemizde üstün ya da özel yetenekli öğrenciler için tam zamanlı gruplama uygulamalarının ise yok denecek kadar az olduğu söylenebilir. Yalnızca İstanbul'da bulunan ARGEMER isimli okul özel yetenekli öğrencilere yönelik ortaokul ve lise düzeyinde eğitim vermektedir. MEB'e bağlı ve resmi olan bu okul dışında birkaç özel ve vakıf okulunda tam zamanlı gruplama yapıldığı bilinmektedir. $\mathrm{Bu}$ açıdan bakıldığında ülkemizde üstün/özel yetenekli öğrencilere yönelik ayrı okul uygulamalarının çok sınırlı olduğu ve etkisi konusunda pratik tecrübelerin yeterli olmadığı söylenebilir.

Üstün yetenekli öğrencilerin eğitimleri için uygulanan gruplama modellerinin ya da diğer eğitim stratejilerinin hangisinin daha yararlı olduğu konusu da tartışmalıdır. Buradaki temel soru: Üstün yetenekli öğrenciler için tam zamanlı ve homojen gruplamalar mı yoksa akranlarıyla aynı ortamda oldukları heterojen ve yarı zamanlı uygulamalar mı daha etkilidir? Bazı araştırmacılara göre ayrı eğitim okulları ve programları üstün yetenekli öğrencilerin hepsi için en uygun ve olumlu eğitim ortamı değildir (Marsh, 2005; Marsh \& Craven, 2006; Marsh \& Hau, 2003, 2004). Ayrı eğitim ortamlarının rekabetçi bir ortama sahip olmasının akademik benlik kavramı ve sosyal karşılaştırma süreçleri bakımından olumsuz etkilerinin olduğu da birçok çalışma ile ortaya konmuştur (Goetz, Prekel, Zeidner, \& Schleyer, 2008; Marsh \& Hau, 2003). Örneğin Marsh ve Hau'nun (2003) 26 farklı eyalette yüz bin öğrenci üzerinde yaptıkları araştırma bulgularına göre ayrı eğitim ortamlarında öğrenim gören üstün yetenekli öğrencilerin normal sınıflarda öğrenim gören öğrencilere kıyasla akademik benlik kavramlarının daha düşük olduğu görülmüştür. Bu durum "büyük balık küçük gölet etkisi" olarak da bilinmektedir (Çitil, 2016). Bazı araştırmacılar da hızlandırma ve zenginleştirme uygulamalarının üstün yetenekli çocuklar için en önemli eğitsel ayarlama olduğu sonucuna ulaşmışlardır (Van der Meulen vd., 2014). Buna rağmen ayrı eğitim uygulamalarının o kadar da olumsuz olmadığını iddia eden araştırmacılar bulunmaktadır (Çitil, 2016).

Bazı araştırmacılar ayrı okulların veya eğitim ortamlarının olumlu etkileri olduğunu iddia etmişlerdir. Bunlara göre özel eğitim ortamlarındaki akademik benlik kavramındaki düşüş mutlaka olumsuz bir durum olmayıp öğrencileri gelecekte karşılaşabilecekleri rekabetçi ortamlara hazırlama olarak görülmelidir (Çitil, 2016; Eddles-Hirsch vd., 2012; McCoach ve Siegle, 2003; Rogers, 2007). Üstün yetenekli çocuklarla ilgili çalışma öğrencilerin toplandığı grupların bu çocukların farklılıklarını kabul eden ve özelliklerini geliştiren ortamlar olduğunu iddia etmektedir (Coleman, 2005; Neihart, 2007). Bazı araştırma sonuçlarına göre de üstün yetenekli 
çocuklar için açılmış ayrı okullar üstün yetenekli çocukların farklılıklarının kabul edilmesi, daha fazla kabul görmeleri, onların akranları tarafından alay edilme korkusu olmadan akademik zorluklarla baş etmeleri için özgür bir ortam sağlamaktadır (Coleman, 2001; Cross, Stewart ve Coleman, 2003).

Alanyazındaki tartışmalar ışı̆̆ında üstün yetenekli öğrencilere sunulan eğitim modelleri ve stratejilerinin hemen hepsinin avantaj veya dezavantajları olduğu görülmektedir. Bu kapsamda üstün yeteneklilerin eğitiminde tek bir doğru model ya da strateji olduğunu söylemek mümkün değildir. ABD'de üstün yeteneklilerin eğitimi konusu Türkiye'den çok daha köklü ve oturmuş bir sisteme sahip olmasına rağmen araştırmacılar; mevcut uygulama ve sorunları araştırma konusu yapmaya devam etmektedirler. Bu kapsamda üstün yeteneklilere yönelik eğitim model ve uygulamalarının incelendiği birçok çalışma olduğu görülmektedir (Alston, 2011; Delcourt vd., 2007; Kulik ve Kulik, 1982; 1992; Noll, 2012; Slavin, 1987; Stelk, 2007; Vaughn vd., 1991 ). Aslında üstün yetenekli çocuklar için sunulan tüm özel eğitim uygulamaları olumlu akademik etkiler göstermektedir. Tam zamanlı gruplamalar ve uyarlanmış müfredat uygulamaları etkili özel eğitim uygulamalarıdır. Daha karmaşık bilgi ve beceriler sunulduğunda üstün yetenekli çocuklarda daha büyük gelişme görülmektedir (Çitil, 2016). Tüm bu tartışma ve bulgular ışığında üstün yetenekli öğrenciler için ayrı okulların faaliyetlerini sürdürdüğü görülmektedir. Üstün yetenekli öğrencilere yönelik ayrı okulların açılmasını ya da açılmamasını fanatik şekilde desteklemek bilimsel bir bakış açısı sayılamaz. Ancak dünyada bu yolu kullanan ve üstün yetenekli öğrencilere yönelik ayrı okullar kuran birçok ülke bulunduğunu bilmek ve bu uygulamaların etkisini anlamak da önemlidir.

Günümüzde en güçlü ekonomiye sahip gelişmiş ülkelerin birçoğunda üstün yetenekliler için açılmış ayrı okullar bulunmaktadır (Çitil, 2018). Bu kapsamda ABD'de Magnet okulları, Dalton ve Hunter Koleji, İsrail'de Ofec Okulları, Rusya'da Kalmogorof Okulları, Güney Kore'de Üstün Yetenekliler Okulları ve Çin'de 8 Numaralı Okullar üstün yeteneklilere yönelik hizmet veren okullar olarak örneklendirilebilir (Bakioğlu \& Levent, 2013; Çitil, 2018; Tekden, 2017). Türkiye'de ise üstün yeteneklilerin tamamına yakını normal gelişim gösteren akranlarıyla aynı ortamda öğrenim görmektedirler. Üstün yetenekli öğrencilere yönelik açılan ayrı okulların içeriği, avantaj ve dezavantajları ise pratikte yeterince bilinmemektedir. Bu çalışmanın genel amacı üstün yeteneklilere yönelik açılan ayrı okulları belli değişkenlere göre incelemektir. $\mathrm{Bu}$ amaç doğrultusunda Amerika kıtasından (ABD ve Kanada) 10 okul çeşitli başlıklarda incelenmiştir. Böylece ayrı okulların yapısı ve işleyişi konusunda okuyuculara, araştırmacı ve uygulamacılara güncel bilgiler sunulmaya çalışılmıştır. 


\section{Yöntem}

$\mathrm{Bu}$ çalışma betimsel bir durum saptaması niteliğinde olduğundan veri toplama yöntemi olarak doküman incelemesi yönteminden faydalanılmıştır. Doküman incelemesi yöntemi, araştırılması hedeflenen olgu ve olgular hakkında bilgi içeren yazılı materyallerin analizini kapsamaktadır (Yıldırım ve Şimşek, 2005, s.187). Bu kapsamda bir dosya inceleme formu oluşturulmuştur. İncelenen okullardan şu başlıklarda veriler toplanmıştır:

- Okulun adı, yeri, kuruluş tarihi

- Okulun resmi/özel olma durumu

- Okul ücreti

- Okulun eğitim düzeyi (ilk/orta/lise)

- Okulun gündüzlü/ yatılı olma durumu

- Sinif mevcudu

- Okulun öğrenci kabul şartları / tanılama yaklaşımı

- Okulda kullanılan eğitim stratejileri, program ve müfredat modelleri

- Okulun sunduğu sosyal, sportif, kültürel faaliyetleri ve diğer özellikleri

Araştırma kapsamında elde edilen veriler betimsel analiz ve içerik analizi yöntemi kullanılarak analiz edilmiştir. Doküman incelemesi sonucunda elde edilen veriler tablolama şeklinde analiz edilmiştir. Bu araştırma incelenen 10 okulla sınırlıdır. Okullar üstün yetenekliler alanında faaliyet gösteren okullardan seçilmiştir. Okullar seçilirken tanınırlıkları ve web sitelerinde sundukları bilgilerin genişliği dikkate alınmıştır. Araştırmacıların hâkim oldukları yabancı dilleri ile bu okulların eğitim dillerinin ve web sitelerindeki dillerin uyumlu olması nedeniyle okullar ABD ve Kanada ülkelerinden seçilmiştir.

\section{Bulgular ve Yorum}

Yukarıda da belirtildiği üzere üstün yetenekli öğrencilere yönelik açılmış olan ve hizmet sunan ayrı okullar bazı değişkenlere göre incelenmiştir. Araştırma kapsamında incelenen okulların ülkelere göre dağılımları, özel ya da devlet okulu olma durumları ve açılış tarihlerine ilişkin bulgular Tablo 
Tablo 1. Üstün Yetenek Okullarının Ülkelere Göre Dağılımı, Özel/Devlet Durumu ve Kuruluş Tarihi

\begin{tabular}{|c|c|c|c|}
\hline Okulun Adı & \multirow{2}{*}{$\begin{array}{l}\text { Ülkesi } \\
\mathrm{ABD}\end{array}$} & \multirow{2}{*}{$\begin{array}{l}\begin{array}{l}\text { Özel/ } \\
\text { Devlet }\end{array} \\
\text { Devlet }\end{array}$} & \multirow{2}{*}{$\begin{array}{l}\begin{array}{l}\text { Kuruluş } \\
\text { Tarihi }\end{array} \\
1975\end{array}$} \\
\hline 1. Edison Regional Gifted Center & & & \\
\hline 2. Galileo School for Gifted Learning & $\mathrm{ABD}$ & Devlet & 2011 \\
\hline 3. Hunter College & $\mathrm{ABD}$ & Devlet & 1870 \\
\hline 4. Dalton School & $\mathrm{ABD}$ & Özel & 1919 \\
\hline 5. OAK Crest Academy & $\mathrm{ABD}$ & Özel & 1976 \\
\hline 6. The Schilling School for Gifted Children & $\mathrm{ABD}$ & Özel & 1997 \\
\hline 7. Vanguard Gifted Academy & $\mathrm{ABD}$ & Özel & 2017 \\
\hline 8. Fern Hill School & $\mathrm{ABD}$ & Özel & 1982 \\
\hline 9. Mentor College & $\mathrm{ABD}$ & Özel & 1982 \\
\hline $\begin{array}{l}\text { 10. PACE (Programing for Academic and } \\
\text { Creative Excellence) }\end{array}$ & Kanada & Devlet & 1993 \\
\hline
\end{tabular}

Tablo 1 incelendiğinde ABD'den 9, Kanada'dan bir okulun araştırma kapsamına dâhil edildiği görülecektir. 10 okulun 4'ü devlet okulu iken diğer 6'sının özel okul olduğu anlaşılmaktadır. Bu okullardan en eski olanının Hunter College (1870 tarihinde kurulmuş), en yenisinin ise Vanguard Gifted Academy (2017 yılında kurulmuş) olduğu anlaşılmıştır. Okulların biri yaklaşık 150 yıllık bir geçmişe sahipken, biri yaklaşık 100 yıllık, ikisi 45 yıllık, biri 38 yıllık bir geçmişe sahiptir. İki okul doksanlı yıllarda kurulmuştur. Diğer iki okulun ise 10 yıldan daha az süre içerisinde kurulmuş olan yeni okullar olduğu anlaşılmıştır. Tüm bu veriler yorumlandığında özellikle ABD'de bir asır öncesinden başlayan bir ayrı eğitim süreci olduğu ve günümüzde de bu okullara yenilerinin eklendiği söylenebilir. Ayrıca hem devletin hem de özel sektörün ayrı okul açma yönünde ilgilerini sürdürdüğü ifade edilebilir.

Araştırma kapsamında incelenen okulların altısının özel okul olduğu dikkate alınırsa bu okulların yıllık ücretlerinin ne olduğunun bilinmesinde de fayda bulunmaktadır. İncelenen okullardan özel olanların ücretlerine ilişkin bulgular Tablo 2'de sunulmuştur. 
Tablo 2. Üstün Yeteneklilere Yönelik Açılan Özel Okulların Ücretleri

\begin{tabular}{llll}
\hline Okulun Adı & $\begin{array}{l}\text { Okulun Ülkesi / } \\
\text { Eyalet / Şehir }\end{array}$ & Okul ücreti \\
\hline 1. & Dalton School & ABD & $54.180 \$$ \\
2. & OAK Crest Academy & ABD & $17-21.000 \$$ \\
3. & The Schilling School for Gifted Children & ABD & $11-17.000 \$$ \\
4. Vanguard Gifted Academy & ABD & $18.500 \$$ \\
5. Fern Hill School & ABD & $11-23.000 \$$ \\
6. $\quad$ Mentor College & ABD & $15-23.000 \$$ \\
\hline
\end{tabular}

Tablo 2 incelendiğinde araştırma kapsamına alınan 6 özel okulun yıllık ücretlerinin 11 ile 55 bin Amerikan Doları arasında değiştiği görülmektedir. Okulların web sitelerine göre sınıf düzeyi ya da öğrencilerin yatılı/gündüzlü olma durumlarına göre fiyatlar kendi içinde de değişmektedir. İncelenen okullar arasında Dalton School'un ücretinin diğerlerine nazaran daha yüksek olduğu görülmektedir (DS, 2020). Diğer okulların yıllık ücretlerinin ise birbirine yakın olduğu anlaşılmaktadır. Bu ücretler ABD ve Kanada'daki diğer özel okulların ücretleri ile kıyaslandığında üstün yetenekliler için açılan okulların ücretlerinin benzer hatta daha uygun olduğu söylenebilir. İncelenen okulların eğitim kademeleri ve sınıf düzeyleri, gündüzlü ya da yatılı olma durumları, sınıf mevcutları ve toplam öğrenci kapasitelerine ilişkin bulgular Tablo 3'te sunulmuştur.

Tablo 3. Okulların Sınıf Düzeyleri, Sınıf Mevcutları, Gündüzlü / Yatılı Olma Durumları ve Toplam Öğrenci Sayı / Kapasitesi

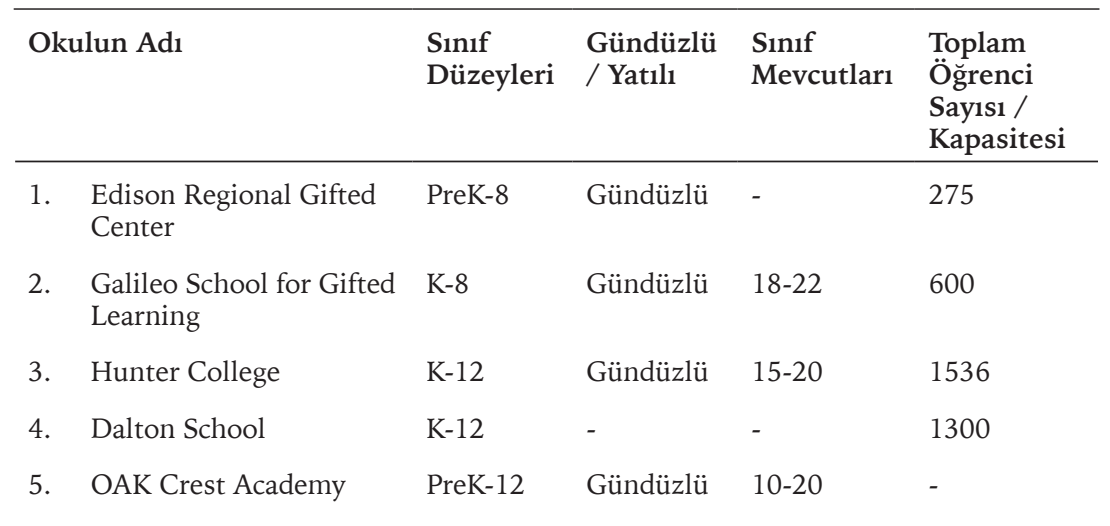




\begin{tabular}{|c|c|c|c|c|c|}
\hline 6. & $\begin{array}{l}\text { The Schilling School for } \\
\text { Gifted Children }\end{array}$ & $\mathrm{K}-12$ & Gündüzlü & 12 & - \\
\hline 7. & $\begin{array}{l}\text { Vanguard Gifted Aca- } \\
\text { demy }\end{array}$ & K-5 & Gündüzlü & - & 1200 \\
\hline 8. & Fern Hill School & $\mathrm{K}-8$ & Gündüzlü & $18-19$ & 400 \\
\hline 9. & Mentor College & $\mathrm{K}-12$ & Gündüzlü & $16-18$ & 1500 \\
\hline 10. & PACE & $1-12$ & Gündüzlü & - & - \\
\hline
\end{tabular}

Tablo 3 incelendiğinde dört okulun K-12 seviyelerinde eğitim verdiği anlaşılmaktadır. Bu kapsamda incelenen okulların yaklaşık yarısının ana sınıfından lise son sınıfa kadar dört kademeyi de içeren eğitim hizmeti sunduğu anlaşılmaktadır. İncelenen okullardan biri (PACE okulu) ise ana sınıfı bulunmamakla birlikte birinci sınıftan lise son sınıfa kadar öğrenim vermektedir. Bir okul da (OAK Crest Academy) okul öncesinden lise son sınıfa kadar öğrenci kabul etmektedir. İki okul ana sınıfından 8. sınıfa kadar öğrenim vermektedir. Okullardan yalnızca biri ana sınıfi-ilkokul kademelerinde öğrenim sunmaktadır. İncelenen okulların tamamı gündüzlü olarak öğrenim vermektedir. Okulların sınıf mevcutlarına bakıldığında ise sınıf mevcutlarının 10-22 arasında değiştiği görülmektedir. Sınıf mevcutları eğitim kademelerine göre değişebilmektedir. Örneğin Oak Crest Academy okulunda anaokulu: 10, ilkokul: 12, ortaokul: 15 kişilik sınıflardan oluşmaktadır (OAK, 2020). The Schilling School for Gifted isimli okulda ise tüm kademelerde sınıf mevcudu 12'dir. Genel olarak değerlendirildiğinde sınıf mevcutlarının düşük olduğu söylenebilir. Araştırma kapsamında incelenen okullardan yedisinin toplam kapasitesi ya da öğrenci sayısına ilişkin bulguya ulaşılabilmiştir. Buna göre okullardaki toplam öğrenci sayısı 275 ile 1536 öğrenci arasındadır. En az öğrenci Edison Regional Gifted Center (275), en fazla öğrenci de Hunter College (1536) okulunda öğrenim görmektedir (ERGC, 2020; HC, 2020).

Üstün yetenekli öğrencilere yönelik hizmet veren okulların bu öğrencileri nasıl kabul ettikleri ve tanıladıklarının anlaşılması da önemlidir. Aşağıda okulların kayıt kabul şartları ve tanılama yaklaşımlarına ilişkin bulgular Tablo 4'te sunulmuştur. 
Tablo 4. Okulların kayıt kabul şartları ve tanılama yaklaşımları

\begin{tabular}{|c|c|c|c|c|c|c|c|c|}
\hline Okulun Adı & 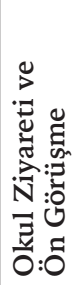 & 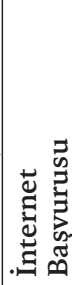 & 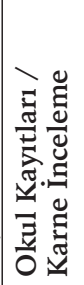 & 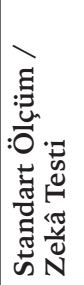 & 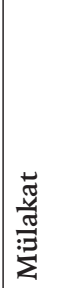 & 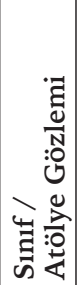 & 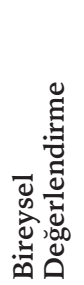 & 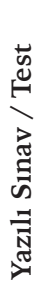 \\
\hline 1. Edison Regional Gifted Center & + & + & - & + & - & - & + & - \\
\hline $\begin{array}{l}\text { 2. Galileo School for Gifted Le- } \\
\text { arning }\end{array}$ & + & + & - & - & - & - & - & \\
\hline 3. Hunter College & + & + & - & + & - & + & + & + \\
\hline 4. Dalton School & + & + & + & + & + & + & + & + \\
\hline 5. OAK Crest Academy & + & + & - & & - & - & - & - \\
\hline $\begin{array}{ll}\text { 6. The Schilling School for } \\
\text { Gifted Children }\end{array}$ & + & + & - & + & - & - & - & - \\
\hline 7. Vanguard Gifted Academy & + & + & - & + & - & - & - & - \\
\hline 8. $\quad$ Fern Hill School & + & + & - & - & + & + & + & + \\
\hline 9. Mentor College & + & + & + & - & + & + & + & + \\
\hline 10. PACE & + & + & - & + & + & + & + & - \\
\hline
\end{tabular}

Tablo 4'e göre incelenen okulların tamamı yüz yüze ya da internet üzerinden başvuru alabilmektedir. İki okul varsa önceki okul ve sınıfındaki durumuna ilişkin kayıtları incelemektedir. İncelenen okullardan yalnızca 3'ü standart ölçüm ya da psikoeğitsel ölçüm şartı aramamaktadır. Okullardan 4'ü öğrencilere mülakat yapmakta, 5'i öğrencileri sınıf ya da atölyelerde gözleyerek değerlendirmekte, 6'sı bireysel değerlendirme yapmakta ve 5'i öğrencilere kendileri yazılı sınav ya da başarı testi uygulamaktadır. Okul bazında işletilen kabul ve tanılama yaklaşımları aşağıda sunulmuştur.

Edison Regional Gifted Center: Bu okula Chicago Devlet Okulları Illinois Teknoloji Enstitüsü tarafından yapılan standart ölçümler ile öğrenci seçiliyor. Burada da düşünme, mantık yürütme, problem çözme, yaratıcılık, zihinsel kontrol (Bellek kapasitesi)'e dayalı ölçümler yapılıyor (ERGC, 2020). Galileo School for Gifted Learning üstün yetenekliler için açılmış bir okul olmasına rağmen okula kayıt / kabul şartı bulunmuyor. Okul zenginleştirilmiş eğitim isteyen velilere ve öğrencilere açık olduğunu 
belirtiyor. Okulda gerekli görülürse web tabanlı online test yapılıyor. Eğer başvuru fazla olursa çekiliş yapılıyor (GSGL, 2020). Hunter Koleji'nde anaokuluna kabul edilen öğrenciler ilkokula devam edebiliyor. Hunter anaokulu için Manhattan'da ikamet eden ve 4 yaşını doldurmuş olanlar başvurabiliyor. Okula başvuran öğrencilere Stanford Binet zekâ testinin son sürümü uygulanıyor (ücretli). Yaklaşık 3 bin başvurunun ardından ilk aşamayı geçip ikinci aşamaya gelebilen öğrenci sayısı genelde 250-300 kişi oluyor. İkinci aşamada özel olarak hazırlanmış değerlendirme odasında çocuğun davranışları gözlemlenerek ebeveynler ve okul öncesi öğretmenleri tarafindan gözlem formu dolduruluyor. Değerlendirmeler Hunter Kabul Seçim Komitesi tarafindan incelenerek $25 \mathrm{kız} 25$ erkek olmak üzere toplam 50 öğrenci seçiliyor. Hunter Koleji’nde ilköğretimden mezun olanlar liseye doğrudan kabul ediliyor. Dışarıdan liseye girmek isteyen öğrenciler 7. sınıfta başvuru yapabiliyor. ERB (Educational Records Bureau), Kapsamlı Test Programı 5 (CTP 5), Newfoundland, Stanford Başarı Testi ve Iowa Temel Beceri Testi (ITBS) gibi sınavların herhangi birinden \%90'lık dilime giren öğrenciler okul tarafından yapılan 3 saatlik bir giriş sınavına alınıyor. Bu sınav, okuma, anlama ve matematik konularını kapsayan çoktan seçmeli bölüm ve makale yazma bölümünden oluşuyor. Makaleye çok önem veriliyor ve en iyi makaleyi yazan 170 kişi okula kabul ediliyor (HC, 2020). Dalton School'a başvuranlardan anaokulundan 3. sınıfa kadar okul kayıtları inceleniyor. ERB testine girmeleri isteniyor (başarıyı ve muhakeme becerilerini ölçen AABL, ECAA testi ve ISEE testleri). Bu testleri geçenler mülakata alınıyor. 4-12. sınıflar için okul kayıtları inceleniyor. Öğrencinin yazı örneklerine bakılıyor. Standartlaştırılmış test (örn. Bağımsız Okula Giriş Sınavı ve Ortaokul Kabul Testi ) sonuçlarına bakılıyor. Düşünme ve katılım aktiviteleri (T\&E Test) değerlendiriliyor. Mülakat yapılıyor. OAK Crest Academy'de doğrudan ya da internet üzerinden başvuru alınıyor. Standart araçlarla tanılama (Stanford Binet (L-M), Wescher Intelligence Scale for Children (WISC) veya Wechsler Preschool and Primary (WPPSI), Woodcock Johnson, CogAT, OLSAT, Hemmon-Nelson, Ravens Progressive Matrices) yapiliyor (DS, 2020). The Schilling School for Gifted Children IQ testine dayalı olarak kabul ediyor. IQ testi okulun akredite ettiği yerlerde yapılabiliyor.130 IQ ve üzeri öğrenciler kabul ediliyor (SSGC, 2020). Vanguard Gifted Academy 6 yaş ve üzeri çocukları IQ testine dayalı olarak kabul ediyor. IQ testi okulun akredite ettiği yerlerde yapılabiliyor. 125 IQ puanı ve üzeri olanlar kabul ediliyor (VGA, 2020). Fern Hill School'da anasınıfları için Etkileşimli Hazırlık Değerlendirmesi yapılıyor. Bu kapsamda sosyal etkileşim ve davranışsal gelişim değerlendiriliyor. 1. ila 3. sınıflara dil ve matematik alanlarında yazılı sınav yapılıyor. Birinci sınıfların okuma bilmesi şartı aranıyor. 4. ve 8. sınıflar için öğrencinin İngilizce dilindeki 
sınıf düzeyini ölçen okuduğunu anlama, yazım, cümle yapısı ve matematik alanında değerlendirme yapılıyor. Değerlendirmelerin ardından mülakat yapılıyor (FHS, 2020). Mentor College'da anasınıflarından 4. sınıfa kadar başvuran tüm aday öğrenciler, ziyaret için İlköğretim Kampüsü’ne davet ediliyor. Öğrencinin varsa önceki okul karnesi ve okulun değerlendirme raporu isteniyor. Anasınıfları ve birinci sınıf öğrencileri 2 saatlik bir değerlendirme etkinliğine alınıyor. 2-4. sınıf öğrencilerinin 1.5 saat boyunca bir sınıfta sınıf düzeyindeki çalışmaları tamamlaması isteniyor. 5-8. sınıf öğrencileri için de okul değerlendirme raporu isteniyor. Ayrıca 5. ve 6. sınıflardaki öğrenciler için 90 dakika ve 7. ve 8. sınıflardaki öğrenciler için 120 dakikalık bir sınav yapılıyor. Sınavda öğrencilerin genel bilgisi, düşünce süreci ve yazılı iletişim becerileri, matematik seviyesi değerlendiriliyor. 9-12 sınıf düzeyinde de ortaokula benzer bir süreç işletiliyor (MC, 2020). PACE'de ise psikoeğitsel testler sonucunda entelektüel olarak yetenekli tanısı alanlar kabul ediliyor. Test sonucu uygun olan öğrenciler mülakata çağrılıyor. Öğrenciler okulda bir gün geçiriyor ve okul tarafindan değerlendiriliyor (PACE, 2020). Genel olarak değerlendirildiğinde incelenen okulların birbirine benzemekle birlikte kendilerine ait bir tanılama ve kabul sistemine sahip oldukları anlaşılmaktadır. Bu kapsamda standart ölçümlerin yanı sıra sürece dayalı ve gelişimsel yaklaşımın tercih edildiği anlaşılmaktadır.

Araştırma kapsamında incelenen okulların üstün yetenekli öğrencilere hizmet verdiği gerçeğinden hareketle bu öğrencilere ne tür bir eğitim verdiklerini de anlamak gerekmektedir. Yapılan incelemeler sonucunda araştırma kapsamında incelenen okullarda kullanılan eğitim stratejileri ve program modelleri Tablo 5'te sunulmuştur.

Tablo 5 incelendiğinde 10 okulda zenginleştirme, 8 okulda hızlandırma, 5 okulda farklılaştırılmış / bireyselleştirilmiş öğretim, 3 okulda STEM, 2 okulda mentörlük, iki okulda da yetenek gruplama stratejilerinin uygulandığı anlaşılmaktadır. Yalnızca bir okul üstün yetenekliler için bilim insanlarınca hazırlanmış müfredat ve program modellerini kullanmaktadır. Okul bazında kullanılan strateji ve modeller ise şöyledir. Edison Regional Gifted Center: hızlandırma, zenginleştirme, STEM; Galileo School for Gifted Learning: zenginleştirme, farklılaştırılmış öğretim, STEM, esnek gruplama; Hunter College: zenginleştirme, hızlandırma, mentörlük; Dalton School: hızlandırma, zenginleştirme; OAK Crest Academy: zenginleştirme, bütünleşik müfredat modeli; The Schilling School for Gifted Children: zenginleştirme, müfredat hızlandırma, yetenek gruplama; Vanguard 2020/2 Gifted Academy: zenginleştirme, farklılaştırılmış öğretim, harmanlanmış öğrenme, proje ve probleme dayalı öğrenme, STEAM; Fern Hill School: 
zenginleştirme, hızlandırma, farklılaştırılmış öğretim; Mentor College, zenginleştirme, hızlandırma (ileri düzey yerleştirme sınıfi), farklılaştırılmış öğretim; PACE: zenginleştirme, hızlandırma, farklılaştırılmış öğretim. İncelenen okullardan yalnızca OAK Crest Academy'nin üstün yeteneklilere yönelik geliştirilmiş bir müfredat modeli kullandığı anlaşılmaktadır (OAK, 2020). Bunlar dışındaki okulların üstün yeteneklilere yönelik genel eğitim stratejileri kullandığı anlaşılmaktadır.

Tablo 5. Okullarda Kullanılan Eğitim Stratejileri ve Program Modelleri

\begin{tabular}{|c|c|c|c|c|c|c|c|c|}
\hline Okulun Adı & 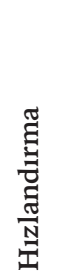 & 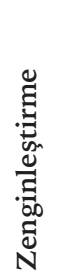 & 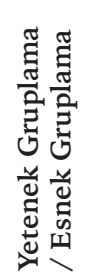 & 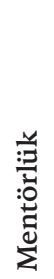 & 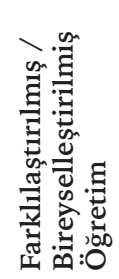 & 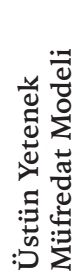 & 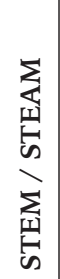 & $\begin{array}{l}\grave{\Delta} \\
\stackrel{\circ}{\circ} \\
\ddot{0}\end{array}$ \\
\hline $\begin{array}{l}\text { 1. Edison Regional Gifted } \\
\text { Center }\end{array}$ & + & + & - & - & - & - & + & - \\
\hline $\begin{array}{l}\text { 2. Galileo School for Gifted } \\
\text { Learning }\end{array}$ & - & + & + & - & + & - & + & - \\
\hline 3. Hunter College & + & + & - & + & - & - & - & - \\
\hline 4. Dalton School & + & + & - & - & - & - & - & - \\
\hline 5. OAK Crest Academy & + & + & - & - & - & & - & \\
\hline $\begin{array}{l}\text { 6. The Schilling School for } \\
\text { Gifted Children }\end{array}$ & + & + & + & - & - & - & - & - \\
\hline $\begin{array}{l}\text { 7. Vanguard Gifted Aca- } \\
\text { demy }\end{array}$ & - & + & - & - & + & + & + & + \\
\hline 8. Fern Hill School & + & + & - & - & + & - & - & - \\
\hline 9. Mentor College & + & + & - & + & + & - & - & -- \\
\hline 10. PACE & + & + & - & - & + & - & - & - \\
\hline
\end{tabular}

Okullarda Kullanılan eğitim stratejileri ve program modelleri arasında hızlandırma ve zenginleştirmenin ön plana çıktığı anlaşılmaktadır. Bu nedenle okulların sunduğu zenginleştirme faaliyetlerinin anlaşılmasında yarar bulunmaktadır. Araştırma kapsamında okulların sunduğu seçmeli ders, atölye ve etkinlikler Tablo 6'da sunulmuştur. 
Tablo 6. Okullarda Sunulan Seçmeli Ders, Atölye ve Etkinlikler

\begin{tabular}{|c|c|}
\hline Okulun Adı & Atölye / Etkinlik / Seçmeli Ders \\
\hline $\begin{array}{l}\text { 1. Edison Regional Gifted } \\
\text { Center }\end{array}$ & $\begin{array}{l}\text { - Dil sanatları, edebiyat, STEM sinıfları, beden } \\
\text { eğitimi ve sağlık }\end{array}$ \\
\hline $\begin{array}{l}\text { 2. Galileo School for Gifted } \\
\text { Learning }\end{array}$ & $\begin{array}{l}\text { - Teknoloji, sanat, müzik, beden eğitimi/sağlık, } \\
\text { programlama, dünya dilleri }\end{array}$ \\
\hline 3. Hunter College & $\begin{array}{l}\text { Fotoğrafçılık, resim, çizim seramik; } \\
\text { gazetecilik, yaratıcı yazma, Asya-Amerikan } \\
\text { edebiyatı, bilim kurgu, ileri deneme yazımı, } \\
\text { oyunculuk, yönetmenlik, topluluk önünde } \\
\text { konuşma, atletizim, güreş, eskrim, kaya } \\
\text { tırmanışı, paten, yoga, aerobik, dövüş } \\
\text { sanatları, golf, bilgisayar bilimi, istatistik, } \\
\text { astrofizik, kozmoloji ve tıbbi fizyoloji, organik } \\
\text { kimya, felsefe, mikro ve makroekonomi; } \\
\text { Latince, İspanyolca, Fransızca, klasik } \\
\text { mitoloji. } \\
\text { Hunter, her öğrencinin mezun olabilmesi } \\
\text { için } 75 \text { saatlik topluma hizmetini yerine } \\
\text { getirmesini istemektedir }\end{array}$ \\
\hline 4. Dalton School & $\begin{array}{l}\text { - } \quad \text { Sanat, teknoloji, atletizm, Çince } \\
\text { - } \quad \text { Yaz kampları } \\
\end{array}$ \\
\hline 5. OAK Crest Academy & $\begin{array}{l}\text { Müzik, görsel sanatlar, performans sanatları, } \\
\text { dil sanatları, matematik, fen, sosyal bilimler, } \\
\text { beden eğitimi sınıfları } \\
\text { - Ağaç işleri, yoga, satranç, roket mühendisliği, } \\
\text { meditasyon atölyeleri }\end{array}$ \\
\hline $\begin{array}{l}\text { 6. The Schilling School for } \\
\text { Gifted Children }\end{array}$ & $\begin{array}{l}\text { - Robotik, bilgisayar bilimi, aikido, satranç, } \\
\text { mitoloji ve yaratıcı yazarlık drama, kostüm } \\
\text { tasarımı, senaryo yazımı ve film analizi, } \\
\text { sanat, çizim, gitar, müzik, eskrim sınıfları } \\
\text { - } \quad \text { Okul korosu } \\
\text { - Çince, Felemenkçe, Fransızıca, Almanca, } \\
\text { Japonca, Latince, Rusça, İsaret Dili ve } \\
\text { İspanyolca dahil olmak üzere } 9 \text { farklı yabancı } \\
\text { dil seçeneği }\end{array}$ \\
\hline 7. Vanguard Gifted Academy & $\begin{array}{l}\text { - Şükran günü gibi çeşitli günlere dayalı okul } \\
\text { çapında etkinlikler } \\
\text { - } \quad \text { Vitrin Gecesi: Öğrenciler öğrendiklerini ve } \\
\text { yeteneklerini sergiliyor. }\end{array}$ \\
\hline
\end{tabular}




\begin{tabular}{|l|l|l|}
\hline 8. Fern Hill School & - $\begin{array}{l}\text { Ylllık, fotoğraf kulübü, sanat kulübü, müzik } \\
\text { grupları, koro, dans, drama, satranç, tartışma, } \\
\text { matematik, fen, robotik, çevre, topluma } \\
\text { hizmet, doğa sporları }\end{array}$ \\
\hline 9. Mentor College & $\begin{array}{l}\text { Y1llık, öğrenci konseyi, okul gazetesi, fotoğraf } \\
\text { kulübü, sanat kulübü, müzik grupları, koro, } \\
\text { yoga, drama, satranç, matematik, fen, robotik, } \\
\text { bilgisayar, çevre, topluma hizmet }\end{array}$ \\
\hline 10. PACE & $\begin{array}{l}\text { Sessiz okuma, yoga, drama, satranç mad } \\
\text { science (çıllgin bilim), müzik, tiyatro, eğlence, } \\
\text { mühendislik, dinazor kulübü, bale grubu, } \\
\text { kukla yapımı, görsel sanatlar, tekvando, koro, } \\
\text { robotik, işaret dili, örgü, origami, dış mekan } \\
\text { sporları, çevre kulübü, yaratıcı problem } \\
\text { çözme, film sanatları }\end{array}$ \\
\hline
\end{tabular}

Tablo 6 ele alındığında araştırma kapsamında incelenen okulların çok farklı ve zengin içerik, etkinlik ve dersler sunduğu anlaşılmaktadır. Bu kapsamda okulların web sitelerinden edinilen bilgilerin bir kısmını burada sunmakta fayda bulunmaktadır. Bu kapsamda ilk olarak Edison Regional Gifted Center'a değinilirse; okulda keşfetme, deneyim kazanma ve yaratıcılık üzerine hızlandırılmış ve zenginleştirilmiş bir program sunulmaktadır (ERGC, 2020). Dalton School okulunda konuya dayalı zenginleştirme ve rehberli bağımsız çalışmalar yapılmaktadır. Okulda yapılandırmacı yaklaşım kullanılmaktadır. Okulda ikinci dil olarak Çince öğretilmektedir (DS, 2020). OAK Crest Academy Dil sanatları ve sosyal bilimler alanındaki öğretim uygulamalarına dair bir çerçeve modele sahiptir (OAK, 2020). Kanada'da bulunan PACE okulunda ise farklılaştırılmış müfredatta tematik yaklaşım ve hızlandırma temelinde eğitim sunulmaktadır. Problem çözme, okuma, yazma, Fransızca, beden eğitimi, görsel sanatlar, fen, matematik dersleri okulda önem verilen dersler arasındadır. Okulda öğrencilerin kendi kendine yeten bireyler olmalarının yolunu açan bir eğitim anlayışı hakimdir. Okulda üstün yeteneklilerin eğitimi alanında sıklıkla kullanılan konu temelli zenginleştirme, müfredat uyarlama, rehberli bağımsız çalışma, (cyberlearning), sınıf içi uyarlama yapma, hızlandırma ve ileri düzey yerleştirme uygulamalarına yer veriliyor (PACE, 2020).

Galileo School for Gifted Learning okulunda ise STEM anlayışı hâkim. Okulda üstün zekalıların eğitimi araştırma yöntemlerine ve etkileşime dayalı (interactive), küresel (global), teknoloji tabanlı ve aktif bir öğrenme 
eğitim sunulmaktadır. Geleneksel sınıf öğretiminden farklı bir işleyiş temel alınan okulda, "Kavramdan önce etkinlik, kelime ve okumadan önce kavram” bilim sınıflarında kullanılan yöntemdir. Alan gezileri, misafir konuşmacılar, filmler, edebiyat, tarihsel dokümanlar, fen laboratuarları öğrencinin etkin fikirlere (key concept) yönelik derin bir anlayış geliştirmelerini sağlar. Matematik ve okuma sınıflarında esnek gruplamadan yararlanılmakta, öğrenciler akademik becerilerde geliştikçe müfredat onların gereksinimlerine göre uyarlanmaktadır. Bunların yanı sıra öğrencilere beslenme ve oyun için yeteri kadar vakit sağlanmaktadır. Okuldaki "Yaratıcı ve Üretken Atölyeler"de kıyafet ve oyuncak tasarlama, ekosistem için bitki ve hayvanların yaşamını araştırma, mühendisliğe dayalı robotik, havacılığa dayalı uçak uçurma/simülasyon uçuşları vb. atölyelerde farklı eğitimler verilmektedir. Galileo School for Gifted Learning okulundaki bütün öğretmenlerin üstün yeteneklilerin eğitimi alanında uzman olduğu belirtilmiştir (GSGL, 2020).

The Schilling School for Gifted Children Okulu bir çocuğun gelişiminin zihinsel, fiziksel, duygusal ve ruhsal yönlerinin besleneceği "tüm çocuk" felsefesini benimsemektedir. Çekirdek müfredat hızlandırma ve yetenek grupları aracılığıyla öğretim yapılmaktadır. Schilling School'da, bireyselleştirilmiş öğrenme seçenekleriyle tipik olarak sınıf seviyesinin 1,5-2 yıl üzerinde üstün yetenekli müfredat sunulmaktadır. Schilling School programında Pazartesi, Çarşamba ve Cuma günleri temel dersler (matematik, fen bilimleri, okuma, dil sanatları, sosyal bilimler), Salı ve Perşembe günleri ise öğrenme deneyimini zenginleştirmek için seçmeli dersler sunulmaktadır. Bu esnek program, yetenek gruplama seçeneklerine izin verir. Örneğin, matematik dersleri ilk, orta ve üst okul boyunca 1. periyotta yapılır. Bir alt okul öğrencisi matematikte ileri düzeydeyse, diğer ders alanlarındaki herhangi bir öğrenme fırsatını kaçırmadan, daha yüksek bir matematik dersindeki beceriye göre gruplanabilmektedir. Program, öğrencilerin ilgi alanları göz önünde bulundurularak tasarlanmıştır ve her üç ayda bir değişebilir (SSGC, 2020).

Vanguard Gifted Academy öğrenme sürecinde işbirlikçi, yaratıcı, bireyselleştirilmiş, üstbilişsel ve analitik bir anlayış hâkimdir. Bu okulun da kendine ait bir modeli bulunmaktadır. Okulda 3 modüle dayalı öğretim söz konusudur. Sabahları (Blended Learning Module) harmanlanmış öğrenme modülünde teknoloji tabanlı bireyselleştirilmiş eğitim fırsatı sunulmaktadır. Öğlen (Community Module) Toplum Modülü kapsamında öğrencilerin sosyal duygusal gelişimlerini, işbirliği, liderlik, problem çözme, toplumsal sorumluluk becerilerini destekleyecek eğitimlere yer verilmektedir. Son olarak proje ve probleme dayalı öğrenme modülü (S.T.R.E.A.M) kapsamında 
eğitim sunularak gün tamamlanmaktadır. Öğrenciler sunumlar, projeler, araştırmalar, simülasyonlar, workshoplar aracılığıyla başlatma, planlama, uygulama, yansıtma, geliştirme, problemlere yönelik çözüm ve ürün üretme becerilerini geliştirme fırsatı yakalamaktadır. Modüller tamamlandıktan sonra zenginleştirme sınıflarında dersler işlenmektedir. Zenginleştirme sinıfları ayrı ücrete tabidir (VGA, 2020).

İncelenen okullar arasında hem köklü bir geçmişe sahip olması hem de devlet okulu olması bakımından Hunter Koleji'ne özel bir yer ayırmak faydalı olabilir. Hunter Koleji’nde müfredat hazırlanırken, üstün yetenekli öğrencilerin eğitimi ulusal standartları kullanılmaktadır. Okulun müfredatı üstün yetenekli öğrencilerin yaratıcı ve eleştirel düşünme becerilerini geliştirmek için tasarlanmıştır. Öğrencilerin konuları derinlemesine incelemeleri, gerektiğinde öğrenmelerini hızlandırmalarını sağlamaktadır. Ebeveynleri de programa dâhil eden bir müfredatları bulunmaktadır. Hunter Koleji öğrencilerinin tarih, matematik, bilim ve sanatta bir denge halinde bütün derslerden öğrenmelerini amaçlamaktadır. Tüm konular, çocukların ileri kelime dağarcığı, sözel akıcılık, güçlü hafıza ve öğrenme stratejilerini genişletme ve yeni bilgi ve görevlere uygulama becerilerine bağlıdır. 4-6. sınıf müfredatında öğretmenlerin mentör olarak rolü, öğrencilerin araştırma ve deneylerde kullanılan stratejileri geliştirmelerine yardımcı olmaktır. Sınıf öğretmenlerinin verdiği eğitimin dışında alanında uzman olan eğitimciler tarafından verilen özel dersler de bulunmaktadır. Bunlar arasında 3 boyutlu inşaat sorunlarını çözme, boyama, kolaj, çizim ve kukla yapımı gibi aktiviteler, kil ve ağaç işleme ile dokunsal ve ince motor becerilerinin gelişmesini sağlayan aktiviteler yer almaktadır. Çocuklar anaokulunda Fransızca, 1. sınıfta İspanyolca, 2. sınıftan 6. sınıfa kadar hem İspanyolca hem Fransızca öğrenmektedirler. Anaokulundan 3. sınıfa kadar öğrencilerin teknoloji becerilerini geliştirmek için projeler ve ödevler için bilgisayar laboratuvarı kullanılmakta, 3. sınıfta tablet, 4-6. sınıflarda kablosuz dizüstü bilgisayar kullanılmaktadır. 7-12. sınıfların müfredatında ise İngilizce, sosyal bilimler, matematik, çevre bilimi, Latince, Fransızca veya İspanyolca, beden eğitimi, sanat tarihi ve stüdyo sanatı, iletişim ve tiyatro, müzik ve sağlık, evrensel çalışmalar, fizik, kimya, biyoloji, bilgisayar bilimi, ABD tarihi gibi dersler yer almaktadır. 11. sınıftan itibaren öğrenciler ayrıca seçmeli dersler alabilmektedir. Seçmeli derslerden bazıları, sanat/müzik alanında, fotoğrafçılık, resim, çizim seramik; İngilizce alanında, gazetecilik, yaratıcı yazma, Asya-Amerikan Edebiyatı, bilim kurgu, ileri deneme yazımı; iletişim ve tiyatro alanında oyunculuk, yönetmenlik, topluluk önünde konuşma; beden eğitimi alanında, kaya tırmanışı, paten, yoga, aerobik, dövüş sanatları; matematik alanında, bilgisayar bilimi, istatistik, problem 
çözme; bilim alanında, astrofizik, kozmoloji ve tıbbi fizyoloji, organik kimya; sosyal bilimler alanında, uluslararası ilişkiler, ABD Hükümeti, ABD anayasa hukuku, felsefe, mikro ve makroekonomi; dünya dilleri alanında, Latince, İspanyolca, Fransızca, klasik mitoloji yer almaktadır (http-1). Hunter Kolejine giriş oldukça rekabetçi ve zor olduğu gibi okulda devam etmekte bir o kadar güçtür. Okula başlayıp mezun olamayan birçok öğrenci olduğu söylenmektedir. Bunun sebebi olarak bazı öğrencilere ödevler ağır gelmektedir, bazıları ise matematik ve fen bilimlerinde daha ünlü okullara geçmektedir. Derslerde olan öğrenci mevcudu devlet okullarına göre daha az sayıdadır. Bazı giriş dersleri 30 kişi, bazı dersler 25 kişiden oluşmaktadır. Üst düzey kurslarda ise 15-20 kişi vardır (Hemphill, 2003). Hunter Koleji öğretmenleri ise, öğrettikleri konularla derinden ilgilenen deneyimli eğitimcilerdir. Hepsinin yüksek lisans derecesi vardır ve bazılarının doktora derecesi vardır. Fakültedeki birçok kişi Hunter Koleji ve/veya Hunter Koleji kampüs okulları mezunlarıdır (http-1). Hunter, her öğrencinin mezun olabilmesi için 75 saatlik topluma hizmetini yerine getirmesini istemektedir. Bu 75 saatin en az ellisini okul dışında öğrencilerin toplumun önemli bir parçası olduklarını hissetmeleri, sorumluluk sahibi olmaları, özgüvenlerini geliştirme, topluma katkıda bulunmanın değerini fark etmelerini teşvik etmek için istemektedir. Öğrencilerin hizmet yükümlülüklerini, 5 yaşından itibaren tamamlamaları beklenmektedir. Öğrenciler bu yükümlülüğü okuldan sonra, hafta sonları veya yaz aylarında yerine getirmektedir. Okulda çok çeşitli etkinliklerle öğrenme ve eğlenme konusunda firsat sağlanmaktadır. Atletizm, golf ve lakros takımları, erkekler ve kadınlar için eskrim, beyzbol, kadın ve erkek güreşi, matematik ekibi, robotik, tartışma grubu, satranç, vokal ve enstrümantal müzik, performans grupları ve tiyatro grupları vardır (HC, 2020).

\section{Sonuç ve Öneriler}

Üstün yeteneklilere yönelik açılan ayrı okulları belli değişkenlere göre incelediğimiz bu araştırmada ayrı okulların yapısı ve işleyişi konusunda okuyuculara, araştırmacı ve uygulamacılara güncel bilgiler sunulmaya çalışılmıştır. Araştırma kapsamında ABD'den 9 Kanada'dan 1 okul incelenmiştir. Bu okullardan 4'ü devlet okulu iken diğer 6'sının özel okul olduğu anlaşılmaktadır. Bu okullardan en eski olanının Hunter College (1870 tarihinde kurulmuş), en yenisinin ise Vanguard Gifted Academy (2017 yılında kurulmuş) olduğu anlaşılmıştır. Tüm bu veriler yorumlandığında özellikle ABD'de bir asır öncesinden başlayan bir ayrı eğitim süreci olduğu ve günümüzde de bu okullara yenilerinin eklendiği söylenebilir. Ayrıca hem 
devletin hem de özel sektörün ayrı okul açma yönünde ilgilerini sürdürdüğü ifade edilebilir. Araştırma kapsamına alınan 6 özel okulun yıllık ücretlerinin 11 ile 55 bin Amerikan Doları arasında değiştiği görülmektedir. Bu ücretler ABD ve Kanada'daki diğer özel okulların ücretleri ile kıyaslandığında üstün yetenekliler için açılan okulların ücretlerinin benzer hatta daha uygun olduğu söylenebilir. Özel okullar maddi durumu yeterli olanlar için bir alternatif olarak yer almakla birlikte özellikle ABD'de üstün yetenekliler için açılmış devlet okulları bulunması önemlidir. Böylece bu çocuklar için farklı eğitim ortamı fırsatı sunulmaktadır. Giriş kısmında da değinildiği üzere üstün yetenekliler için tek ve doğru bir model bulunmamakta, ayrı okullar bazı üstün yetenekli öğrenciler için faydalı olabilmektedir (Coleman, 2005; Çitil, 2016; Eddles-Hirsch vd., 2012; McCoach ve Siegle, 2003; Neihart, 2007; Rogers, 2007).

Araştırma kapsamında incelenen dört okulun K-12 seviyelerinde eğitim verdiği anlaşılmaktadır. Bir okul da birinci sınıftan 12. sınıfa kadar eğitim vermektedir. Bu açıdan bakıldığında Amerika'daki okulların okul öncesinden üniversiteye kadar geniş bir yelpazede üstün yetenekli öğrencilere yönelik hizmet verdikleri görülmektedir. Bu anlamda da üstün / özel yeteneği erken yaşta belirleyip uzunca bir süre bu yetenekleri geliştirmeye çalışan bir yaklaşım olduğundan bahsedilebilir. İncelenen okulların tamamı gündüzlü olarak öğrenim vermektedir. Ancak bu araştırma 10 okulla sinırlı olduğundan yatılı okullar olup olmadığı ortaya koyulamamıştır. Doğrudan üstün yetenekliler için açılmış olmasa da $A B D$ ve Kanada'da üstün yetenekli öğrencilerin de devam ettiği yatılı okullar bulunmaktadır. Ancak çağımızın modern anlayışı gereği öğrencilerin ailelerinin yanında kalarak okula gündüzlü devam etmelerinin bir tercih sebebi olduğu söylenebilir. Okulların sınıf mevcutlarına bakıldığında ise sınıf mevcutlarının 10-22 arasında değiştiği görülmektedir. Sınıf mevcutları eğitim kademelerine göre değişebilmektedir. Bu açıdan bakıldığında da yetenekli öğrencilerin daha işlevsel bir ortamda eğitim gördükleri söylenebilir. Sınıf mevcudun az olması eğitim öğretimin kalitesi açısından tartışmasız faydalı bir durumdur. Okullardaki toplam öğrenci sayısı 275 ile 1536 öğrenci arasındadır. Bu sayı okuldaki kademe sayısına ve fiziksel koşullara göre artabilmekte ya da azalabilmektedir. Önemli olan tüm öğrencilere eşit ve zengin fırsatlar sunabilmektedir. İncelenen okulların mevcudu ne olursa olsun bu konuda bir sorun yaşamadıkları görülmektedir.

Üstün yetenekliler için açılmış okulların belki de en önemli farklarından biri öğrenci seçme, kabul şartları ya da tanılama süreçleridir. İncelenen okulların tamamı yüz yüze ya da internet üzerinden başvuru alabilmektedir. İki okul önceki okul ve sınıfındaki durumuna ilişkin kayıtları incelemektedir. 
Incelenen okullardan yalnızca 3'ü standart ölçüm ya da psikoeğitsel ölçüm şartı aramamaktadır. Okullardan 4'ü öğrencilere mülakat yapmakta, 5’i öğrencileri sınıf ya da atölyelerde gözleyerek değerlendirmekte, 6'sı bireysel değerlendirme yapmakta ve 5'i öğrencilere kendileri yazılı sınav ya da başarı testi uygulamaktadır. Genel olarak değerlendirildiğinde incelenen okulların birbirine benzemekle birlikte kendilerine ait bir tanılama ve kabul sistemine sahip oldukları anlaşılmaktadır. Bu kapsamda standart ölçümlerin yanı sıra sürece dayalı ve gelişimsel yaklaşımın tercih edildiği anlaşılmaktadır. Hangi model uygulanırsa uygulansın incelenen okulların ortalama üstü olan öğrencileri okullarına kabul ettikleri anlaşılmaktadır. Bu uygulamaların ise alanyazına uygun olduğu söylenebilir (Sak, 2010; Bildiren ve Çitil, 2019). İncelenen okullarda kullanılan eğitim stratejilerine bakıldığında ise 10 okulda zenginleştirme, 8 okulda hızlandırma, 5 okulda farklılaştırılmış / bireyselleştirilmiş öğretim, 3 okulda STEM, 2 okulda mentörlük, iki okulda da yetenek gruplama stratejilerinin uygulandığı anlaşılmaktadır. Yalnızca bir okul üstün yetenekliler için bilim insanlarınca hazırlanmış müfredat ve program modellerini kullanmaktadır. Okullar üstün yetenekliler için oluşturulmuş genel stratejileri kendi tarzlarında uygulamaktadırlar. Bu anlamda tek tip bir eğitim modelinin bulunduğunu söylemek güçtür. Zaten üstün yeteneklilerin eğitimi bir özel eğitim alanı olduğundan bu öğrencilere farklı eğitim stratejilerini zengin bir çeşitlilikle uygulamak gerekmektedir (Ataman, 2009). İncelenen okulların çok zengin içerik, etkinlik ve dersler sunduğu anlaşılmaktadır. Bu anlamda okulların müfredat yapısı, sosyal, kültürel ve sportif imkânları üstün yetenekli öğrencilerin çok yönlü ve yetenek temelli olarak yetişmesi için güçlü bir zemin sunmaktadır. Ayrı okulların varlığı ve gerekliliği halen tartışılsa da bu okulların kendi içinde bir tutarlığa ve uzmanlığa sahip olduğu, ortalama üstü yeteneğe sahip öğrenciler için bir alternatif olarak varlığını güçlü bir şekilde sürdürdüğü görülmektedir.

Günümüzde eğitim, öğrencilerin farklılıklarına ve gereksinimlerine göre kendini yeniden yapılandırma yoluna gitmiştir. Kapsayıcı ve bütünleştirici eğitim yaklaşımı ve farklılaştırılmış öğretim uygulamaları okulları bu yönde değişime zorlamaktadır. Bu kapsamda üstün ya da özel yetenekli öğrencilerin ve diğer özel gereksinimli öğrencilerin olağan gelişim gösteren akranlarıyla aynı ortamlarda öğrenim görmeleri çok daha geniş bir kitle tarafından ve bilimsel araştırmalar tarafından desteklenmektedir. Ancak özel gereksinimli öğrencilerin bu gereksinimlerine yönelik kendini ayarlamayan okullarda bu çocukların gelişimleri de risk altındadır. Bu nedenle Türkiye gibi yüksek nüfuslu ülkelerde yalnızca bir model ile yola devam etmenin türlü riskleri bulunmaktadır. Bu bağlamda önerimiz kapsayıcı ve bütünleştirici bir eğitim 
modelini tüm şart ve imkânlarıyla en etkili hale getirmek için önlemler alınması yolundadır. Bu bağlamda örgün eğitim kurumlarının personelinin eğitimi, programlarının esnek bir yapıya kavuşturulması, farklılıklara duyarlı bir okul iklimi oluşturulması, öğrenmeyi destekleyecek materyallerin sağlanması, öğrencilerin ilgi ve yeteneklerini geliştirebilecekleri müfredat dışı ders ve atölyelerin oluşturulması gibi önlemler ivedilikle alınmalıdır. Ayrıca örgün eğitim kurumlarında zenginleştirme, hızlandırma ve mentörlük gibi eğitim stratejilerinin uygulamaları yaygınlaştırılabilir. Ancak tüm bu önlemlere rağmen bazı öğrencilerin yeteneklerinin, sosyal ve duygusal ihtiyaçlarının desteklenmesi konusunda sınırlı kalınabilir. Bu nedenle de hem kamu hem de özelde üstün yetenekli öğrenciler için farklı gruplama modelleri de denenebilir.

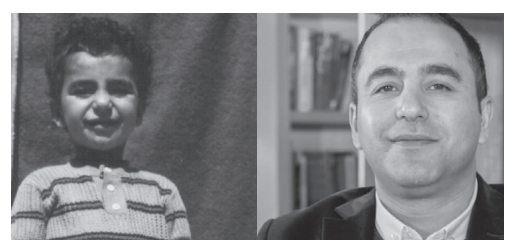

Mahmut Citil

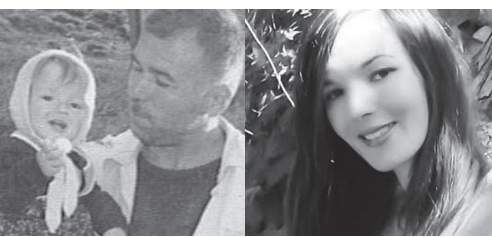

Sıdıka Ersoy

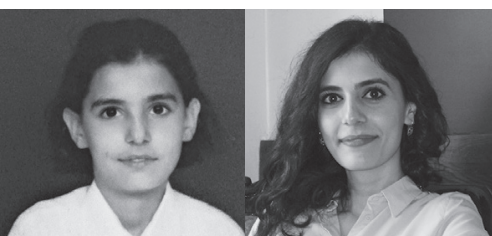

Merve Özdemir-Kılı̨

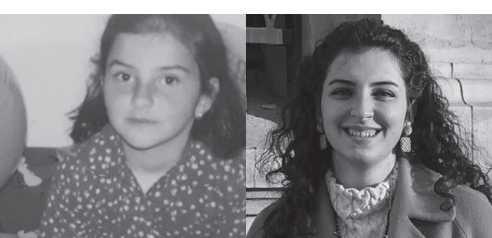

Ayșıl Ağaya

Bu makalenin bir kısmı 3. Uluslararası Türk Dünyası Eğitim Bilimleri ve Sosyal Bilimler Kongresi'nde sunulmuştur. 


\section{Kaynakça}

Akkanat, H. (2004). Üstün veya özel yetenekliler. M.R. Șirin, A. Kulaksızoḡlu, A. E. Bilgili.(Haz.). Üstün Yetenekli çocuklar seçilmiș makaleler kitabı içinde (s. 169 - 194). İstanbul: Çocuk Vakfı.

Alston, A. (2011). Having our say: Thoughts, perspectives, and perceptions of graduates of Satellite East Junior High School for the gifted and talented. Doctoral Dissertation, Teachers College, Columbia University, Columbia

Ataman, A. (Ed.). (2009). Özel Gereksinimli çocuklar ve özel eḡitime giriș. (7.Baskı) Ankara: Gündüz.

Bakioḡlu, A. \& Levent F. (2013). Üstün yeteneklilerin eḡitiminde Türkiye için öneriler. Üstün Yetenekli Eḡitimi Araștırmaları Dergisi, 1(1), 31-44

Bildiren, A. \& Çitil, M. (2019). Özel yeteneklilerin tanılanması. Kılıç, O. \& Çitil, M. (Ed.) Özel Yetenekli Öğrencim Var içinde (223). Ankara: MEB Yayınları

Callard-Szulgit, R. D. (2010). Parenting and teaching the gifted. R\&L Education.

Coleman, L. J. (2001). A rag quilt: Social relationships among students in a special high school. Gifted Child Quarterly, 45 (3), 164-173.

Coleman, L. J. (2005). Nurturing talents in high school. Life in the fast lane. New York, NY: Teachers College Press.

Cross, T. L., Stewart, R. A., \& Coleman, L. (2003). Phenomenology and its implications for gifted studies research: Investigating the Lebenswelt of academically gifted students attending a primary magnet school. Journal for the Education of the Gifted, 26, 201-220.

Çitil, M. (2016). Üstün yetenekli öḡrencilere sunulan olumlu davranıșsal destek temelli problem davranıșları önleyici sinif yönetimi uygulamalari: Eylem Araștırması. Gazi Üniversitesi Eḡitim Bilimleri Enstitüsü, (Yayımlanmamıș Doktora Tezi), Ankara, Türkiye

Citil, M. (2018). Türkiye'de üstün yeteneklilerin eḡitimi politikalarının deḡerlendirilmesi. Milli Eğitim Dergisi, 47 (ÖZEL SAYI 1), 143-172.

Delcourt, M. A. B., Cornell, D. G., \& Goldberg, M. D. (2007). Cognitive and affective learning outcomes of gifted elementary school students. Gifted Child Quarterly, 51(4), 359-381.

DS (2020). Dalton School resmi web sitesi. https://www.dalton.org/

ERGC (2020). Edison Regional Gifted Center resmi web sitesi. https://edisongifted.com/

Eddles-Hirsch, K., Vialle, W., McCormick, J., and Rogers K (2012). Insiders or outsiders: The role of social context in the peer relations of gifted students. social and emotional dimensions of giftedness. Roeper Review, 34, 53-62. DOI: 10.1080/02783193.2012.627554

Enç, M. (2005). Üstün Beyin Gücü . Ankara: Gündüz.. (Ilk Baskı: 1979: Üstün Beyin Gücü. Ankara: A.Ü. Eḡitim Bilimleri Fakültesi).

FHS (2020). Fern Hill School resmi web sitesi. https://www.fernhillschool.com/

Goetz, T., Preckel, F., Zeidneer, M., \& Schleyer, E. (2008). Big fish in big ponds: A multilevel analysis of test anxiety and achievement in special gifted classes. Anxiety, Stress and Coping, 21, 185-198.

GSGL (2020). Galileo School for Gifted Learning resmi web sitesi. https://www.galileogiftedschool. org/

HC (2020). Hunter College resmi web sitesi. https://hunter.cuny.edu/

Kulik, C. L. C., \& Kulik, J. A. (1982). Effects of ability grouping on secondary school students: A metaanalysis of evaluation findings. American Educational Research Journal, 19(3), 415-428.

Kulik, J. A., \& Kulik, C. L. C. (1992). Meta-analytic findings on grouping programs. Gifted Child Quarterly, 36(2), 73-77.

Marsh, H. W. (2005). Big-fish-little-pond effect on academic self-concept. German Journal of Educational Psychology, 19, 119-127.

Marsh, H. W., \& Craven, R. G. (2006). Reciprocal effects of self-concept and performance from a multidimensional perspective: Beyond seductive pleasure and unidimensional perspectives. Perspectives on Psychological Science, 2, 133-163.

Üstün Yeteneklilerin Eğitiminde Ayrı Okullar: Amerika'daki Üstün Yetenekliler Okullarının Karşılaştırmalı Olarak İncelenmesi 
Marsh, H. W., \& Hau, K. T. (2003). Big-fish-little-pond effect on academic self-concept: A cross-cultural (26-country) test of the negative effects of academically selective schools. American Psychologist, 58, 364-376.

Marsh, H. W., \& Hau, K. T. (2004). Explaining paradoxical relations between academic self-concepts and achievements: Cross-cultural generalizability of the internal-external frame of reference predictions across 26 countries. Journal of Educational Psychology, 96, 56-67.

MC (2020). Mentor College resmi web sitesi. https://www.mentorcollege.edu/

McCoach, D. B., \& Siegle, D. (2003). The structure and function of academic self-concept in gifted and general education students. Roeper Review, 25, 61-65.

OAK (2020). OAK Crest Academy resmi web sitesi. https://oakcrestacademy.org/

Neihart, M. (2007). The socioaffective impact of acceleration and ability grouping: Recommendations for best practice. Gifted Child Quarterly, 51, 330-341.

Noll, L J. B. (2012). lowa educators' perceptions on talented and gifted alternative education high school students. Doctoral Dissertation, School of Graduate Studies Western Illinois University.

Rogers, K. B. (2007). Lessons learned about educating the gifted and talented: A synthesis of the research on educational practice. Gifted Child Quarterly, 51, 382-396.

Sak, U. (2010). Üstün zekâlılar (özellikleri, tanılanmaları eḡitimleri). Ankara: Maya Akademi

Slavin, R. E. (1987). Ability grouping and student achievement in elementary schools: Best evidence synthesis. Review of Educational Research, 57(3), 293-336.

SSGC (2020). The Schilling School for Gifted Children resmi web sitesi. https://www.schillingschool. org/

PACE (2020). Programing for Academic and Creative Excellence - PACE resmi web sitesi. https://pace. ca/

Stelk, W. L. (2007). The state gifted education in Nebraska. Doctoral Dissertation, Faculty of The Graduate College at the University of Nebraska.

Tekden, K. (2017). Yerüstü Hazinelerimiz, TÜZDEV Yayınları, İstanbul.

Tortop, H. S. (2012). Olaḡanüstü üstün yetenekli öḡrencilerin eḡitim sürecinde radikal hızlandırma ve Türkiye'nin durumu. Yüksekögretim ve Bilim Dergisi. Journal of Higher Education and Science, 2(2), 106-113.

Van der Meulen, R. T., van der Bruggen, C. O., Spilt, J. L., Verouden, J., Berkhout, M., \& Bögels, S. M. (2014). The pullout program day a week school for gifted children: effects on social-emotional and academic functioning. In Child \& Youth Care Forum (Vol. 43, No. 3, pp. 287-314). Springer US.

Vaughn, V., Feldhusen, J. F., \& Asher, J. W. (1991). Meta-analysis and review of research on pull-out programs in gifted education. Gifted Child Quarterly, 35, 92-98.

VGA (2020). Vanguard Gifted Academy resmi web sitesi. https://vanguardgiftedacademy.org/

Yıldırım, A. ve Șimșek, H. (2005). Sosyal bilimlerde nitel araștırma yöntemleri. Ankara: Seçkin Yayınları 